ANNA SIKORA*

\title{
Dom w „mieście-osiedlu”
}

\section{House in the "city-estate"}

Streszczenie

Myśląc o strukturze funkcjonalno-przestrzennej małych miast z reguły mamy przed oczami niewielkie w skali miasteczko z himianta mérodek miejki, gdzie zespół zabudowy mieszkaniowej wielorodzinnej petni funkcje śródmieścia co buduje specyficz tożsamość miejsca.

$W$ artykule przedstawiono przykłady budowy i przekształceń struktury miejskiej wybranych jednostek osadniczych. Pojẹcie sposobem użytkowania oraz jako małe miasto (tytułowe miasto-osiedle), które pełni funkcje zarówno jednostki sasiedzkie mających wpływ na procesy zmieniające anonimowe, schematyczne układy urbanistyczne osiedli przyzakładowych w wielofunkcyjny "dom", zaprojektowany w sposób dający szanse na poziom komfortu zamieszkania właściwy tradycyjnym modeom miasta o historycznej proweniencji.

Abstract

When thinking about the functional and spatial structure of small towns, we usually have a small town in front of our eyes with a historically shaped market square, surrounded by tenement houses and fine-grained peripheral tissue. There are also small towns, which arose from the $20^{\text {nt }}$ century factory workers' settlements, which in time evolved into a monofunctional urban centre, where the multi-family housing complex functions as a downtown, which builds the specific identity of the place. The article presents examples of construction and transformation of the urban structure of selected settlement units. The

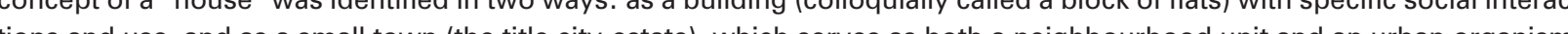
lons and use, and as a small town (the title city-estate), which serves as both a neighbourhood unit and an urban organism. When analysing morphological transformations, the author attempts to indicate the features and factors affecting processes that gives the chance of a level of comfort of living typical of traditional city models with historical provenance.

Stowa kluczowe: mate miasta, dom, zabudowa wielorodzinn

1. Wstęp

Miasto jest podstawową, złożoną strukturą zamieszkania. Relacje, powiązania i przepływy w takiej jednostce ksztaltują się latami i przy zachowaniu stałego natężenia czynników miastotwórczych zmieniają się w sposób umiarkowany. Glownymi progami rozwojowymi takiego

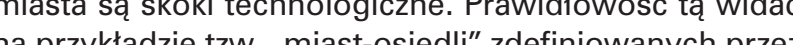
autorke jako miasta wyroste na surowym korzeniu gazie zalażkiem jednostki był układ funkcionalno-przestrzenny wytwórnia-zespół zabudowy wielorodzinnej (osiedle Wielorodzinne). W Polsce takie jednostki powstawa gtównie w okregach (obszarach) przemystowych gdzie funkcjonowata tradycyina (wydobycie) lub nowo lokowana gałaź przemysłu (np. cukrowa mleczna, zbrojeniowa czy inna) wymagajaca stworzenia miejsc zamieszkania dla napływowej kadry pracowniczej.

$W$ obszarze zainteresowań badawczych autorki znajduje się Centralny Okręg Przemysłowy (COP) założony w ramach jednego z działań odbudowy Polski po odzyskaniu niepodległości w $1918 \mathrm{r.}$. Specyfika tego regionu polega na różnorodności przedsięwzięć inwestycyjnych, zarów-

\section{Introduction}

The town is the basic, complex structure of residence. Relations, connections and flows in such and while maintain ing a constant intensity of city-forming factors, they change in a moderate manner. Technological leaps This regularity can be

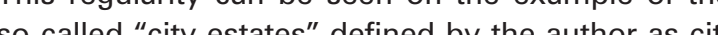
les grown on a raw root, where the function as citgetian a dout, where the functional and complex (multifamily housing estate) was the nucleus of the unit. In Poland, such units were established mainly in indurtial disticts (areas) where a trational (mining) or newly located branch of industry (e.g. sugar, dairy, armament or other) operated, requing the creation of housing for the inflow of employees. The author's research interests include the Centra Industrial District (CID) founded as part of one of Poand's reconstruction activities after regaining independence in 1918. The specificity of this region lies in the diversity of investment projects, both in terms no w odniesieniu do funkcji jak i sposobu budowy (na już istniejacych jednostek osadniczych). Osiedla COP są rowniez charakterystyczne ze względu na przekrö klasowy mieszkancow oraz procesy społeczne, któr towarzyszyły inwestycjom. Okręg powstał w terenac zdegradowanych o niskim kapitale społecznym, gdzi pracowników wykwalifikowanych, zarówno z kadry urzędniczej jak i majsterskiej trzeba było sprowadzac $z$ innych regionów kraju a co za tym idzie zapewnić in w miare komfortowe miejsce do życia'.

\section{Osiedla przyfabryczne i ich mieszkańcy}

W ramach inwestycii Centralnego Okręgu Przemysło wego powstało wiele zakładów przemysłowych oraz ploków, niewielkich zespołów lub całych osiedli przyzakładowych2. Wydaje się, że najbardziej naną inwestycją obszaru COP jest nowe, budowane na urowym korzeniu, miasto - Stalowa Wola. Ze względu broń cięż Zakładów (Południowych) wy Ze wząerch bryszłego miasta, mieszkaniowo-usługowa strukture towarzyszaca zaprojektowano z rozmachem zakładając, że efektem końcowym bedzie kompletna jednostka miejska. Kompozycja mia będzie rała sie o wachlarzowy układ komunikacyjny a wzdłuz ulic zaproponowano proste układy budynków: linijkowe i grzebieniowe.

nnym miastem projektowanym w całości była Poniatowa, która zaplanowana została jako jednostka dużo mniejsza ale kompletna. Zalążiem miasta były Zakłady Tele-i Radiotechniczne (pierwotnie o przeznaczeniu wojsowym). Podobnie jak w przypadku Stalowej Woli budynki mieszkalne ustawione były głownie grzebieniowo. Zaproponowano rowniez przestrzenie publiczne i główną aleję usługową (układ pierzejowy).

Zupełnie inaczej zaprojektowano osiedla towarzyszace inwestycjom o charakterze militarnym takim jak Wywornia Amunicji nr 3 w Nowej Dębie, Fabryka Związków Organicznych Nitroza w Nowej Sarzynie, Wytwórnia Prochu i Materiałów Kruszących w Pionkach (poprzednia nazwa Zagożdzon). Dla pracownikow wybudowano mniej (Pionki) lub bardziej (Nowa Dęba, Nowa Sarzy na) przemyślane zespoły zabudowy, od pojedynczych obiektow do niewielkich zespołów zabudowy jedno i wielorodzinnej. Wymienione powyżej osady, prawdoI Woine Świtowa i w Polsce socjalstyczoj daloj rozwijety produkcie oraz strukture mieszaniowo-ustugowa stopniowo nabywajac funkcjonalno-przestrenne atrybuty miejskści oraz wraz z uzyskaniem praw miejskich (Stalowa Wola 1945 r Pionki 1954 r Nowa Deba 1961 Poniatowa 1962 r.. Nowa Sarzyna 1973 r.) legitymacie do dynamicznego rozwoju poprzez zwiekszanie zaludnien i rozbudowe tkanki o charakterze miejskim. $Z$ czasem te budowane na surowym korzeniu osady przekształcity się w małe miasta (miasta-osiedla).

Kim byli mieszkańcy tych specyficznych miast? Odpowiedź na to pytanie nie jest prosta. W okresie mie dzywojennym, w czasie lokowania pierwszych struktu osiedli przyfabrycznych społeczność składała się z na- of function and method of construction (on a raw settlement units. ecause of the class cross-section of residents an social processes that accompanied the investments. The district was established in degraded areas with low social capital, where qualified employees, both from clerical and foreman staff, had to be brought wom other regions of the country and thus provided with a reasonably comforis

\section{Factory estates and their inhabitants}

As part of the Central Industrial District investment many industrial plants and individual blocks, smal complexes or entire factory estates were established? It seems that the most well-known investment in the CID area is a new, built on a raw root, city - Stalowa Wola. Due to the size of the (Southern) plants manufacturing heavy weapons - currently the Stalowa Wola ironworks and the plants that are the rudiment of the future city, the housing and service accompanying structure was designed on a big scale assuming that the end result will be a complete municipal unit. The composition of the city was based on a fan-shaped comm streets simple bulling layouts were proposed: ruler and comb-style. Another entirely designed town was Poniatowa, which was planned as a much smaller but complete unit. The Weed of the city were the Tele- and Radio Engineering Plants (originally for military use). As in the case of Stalowa Wola, the residential buildings were arranged mainly in the comb-style. Public spaces and the main sevice avenue (frontage layout) were also proposed. Setlements accompanying military investments, such as the Ammunition Factory no. 3 in Nowa Dęba, NiPoza Organic Compounds Factory in Nowa Sarzyna, Pow Pletely de asożzzon) were designed in a com(Nowa Dęba, Nowa Sarzyna) well-thought-out building comto The above- and mult-family housing complexes. the abecifity of productioments, probably due to and in and the housing and service structure, gradually acquiring function and spatial attributes of the city and Wo Whi 1954, Now Deba 1961, Poniatowa 1962, Nowa Saryn 1973) a legitimacy for dymamic development by increasing population density and developing the by matter. Over time, these settlements built on raw root tranformed into small cities (city-estates) Who were the inhabitants of these specific cities? The answer to this question is not easy. In the interwar period, when the first structures of the factory estates were located, the community consisted of an influx of qualified senior staff: directors, managers, officials, engineers and foremen. Workers, in turn, came
from both the surrounding cities and were visitors, tempted by the broad propaganda of the Central In- 
pływowej wykwalifikowanej kadry wyższej: dyrektorow, kierownikow, urzędnikow, inzynierow i majstrów. Robotnicy z kolei wywodzili się zarówno z okolicznych miejscowosci jak i byli to przyjezdni, skuszeni szerok propagandą Centralnego Okręgu Przemysłowego jako regionu dynamicznego rozwoju. Miejscowi wywodzil się głownie z rodzin rolniczych, ktore w częsci zmuszon były sprzedać ziemie „pod inwestycje". Na terenie rodzacego się COP panowało duże bezrobocie gdyż napływ ludzi chętnych do pracy był tak duży, że nie wszyscy ja otrzymywali. Zwiększała się przestępczośćs. Ustabilizowanie sytuacji nastapiło dopiero po II Wojnie Światowej. Wtedy też luźne układy urbanistyczne były uzupełniane i zaczynały tworzyć zwarte struktury nawiazzujace pseudo kwartalowym ukladem do sródmieśc dużych miast a spotałceniu czy pochodzeniu.

\section{Miasto jako dom, dom w strukturze miasta}

ym. Wielki słownik PWN podaje aż siedem podstawowych definicji słowa "dom" są to "budynek przeznaczony na mieszkania lub zakłady pracy", "mieszkanie lub pomieszczenie, w którym się mieszka”, "rodzina, domownicy; też: mieszkanie wraz z jego mieszkańcami", "ogół spraw związanych z rodziną i gospodarstwem", "ród, rodzina, dynastia", "miejsce, z ktorego ktoś pochodzi" a także "instytucja dzielnym lokalu lub budynku; też: budynek, w którym się ona znajduje". Definicje te opisują dom poczynajac od podkreślenia czysto technicznych atrybutów miejsca do mieszkania poprzez kwestie związane z rodziną i gospodarstwem aż do mocno nacechowanego emocjonalnie miejsca pochodzenia. W socjologii zamieszkiwania określenie „dom" kojarzy się z poczuciem zakorzenienia, jest schronieniem oraz punktem odniesienia, symbolem stałości. „Dom” to więzi, posiadanie, przynależność oraz bezpieczeństwo. W takim kontekście domem nie jest tylko budynek ale również sąsiedztwo, miasto, tzw. „mał ojczyzna"s.

Nowe zespoły osadnicze COP funkcjonowaty na początku jak dobrowolne obozy pracy. Pracownicy żywil się $w$ stołówkach a rozrywki zapewniały im zakładowe domy kultury. Rejony zamieszkania, budynki oraz wielkości i wyposażenie mieszkan było zhierarchizowane. W Stalowej Woll i Nowej Dębie powstafy osiedla - kocepcja zagospodrowania $i$ jej relizajia byly naibardziej zawansowane powstaly strefy: osiedle dyrektorskie (gdzie przewidziono ŕ́ urzedników) kolonia urzednicza i kolonia majstersk oraz osiedle robotnicze Podobna segregacje klasowa stworzono w Nowej Debie z tym, że w duż mnieisze skali. Tak rozplanowane jednostki osadnicze nie dawały dużej szansy na wytworzenie wspólnoty Plany Poniato wej $\mathrm{i}$ Nowej Sarzyny były dużo bardziej egalitarne. Powstały osiedla (w przypadku Poniatowej zrealizowano jedynie niewielki fragment planu) gdzie na stosunkowo niewielkiej powierzchni zlokalizowano bloki przeznaczone dla kadry inżynierskiej i urzędniczej oraz dla majstrów robotników. Budowę miast przerwała wojna podcza dustrial District as a region of dynamic development. were partly forced to sell the land "for investments" In the emerging CID area, there was high unemployment because the influx of people willing to work was so high that not everyone received it. Crime has increased. The situation stabilized only after World War II. At that time, loose urban layouts were supplemented and began to form compact strucures reminiscent of the pseudo-quarter layout to the downtowns of large cities, and communities were integrated despite differences in education or origin.

\section{City as a home, a house in the city structure}

The concept of a house is a complex concept. The great PWN dictionary provides as many as seven ba sic definitions of the word "house - "building for flats "family, hoces", apartment or room where you live" "all m, hars rates, also: a fat wh its inhabitants",

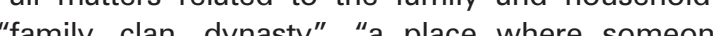
"camily, clan," dy noly", "a plily and ho someone usully located in a separate premises or building Iso: a building in which it is located". These definitions describe the house, from emphasizing the purely technical attributes of the place to live, through is sues related to the family and the farm, to the strongly emotionally marked place of origin. In the sociology of habitation, the term "house" is associated with a sense of rooting, a shelter and a reference point a symbol of permanence. A "house" means bonding ownership, belonging and security. In this context, home is not only a building but also the neighbourhood, the city, the so-called "little homeland"5.

At first, the new CID settlement complexes functioned as voluntary labour camps. Employees ate in canteens and entertainment was provided by company culture centres. Areas of residence, buildings as well as sizes and equipment of flats were hierarchical. Housing estates were created in Stalowa Wola and Nowa Dęba - colonies separated by forests. In Stalowa Wola, where the concept of development and its implementation were the most advanced, zones were created: a director's housing estate (where housing for senior officials was also provided), an official and foreman colony, and a workers housing estate. A similar class segregation was created in Nowa Dęba, but on a much smal er scale. The settlement units planned in this was did not give a great chance to create a community. The plans of Poniatowa and Nowa Sarzyna were much more egalitarian. There were created estates (in the wase was implemented), where blocks intended for engineering and official staff, as well as workers' foremen were located on a relatively small area of land. The construction of cities was interrupted by the war during which the buildings built in 1937-1939, both Unfory and reside by

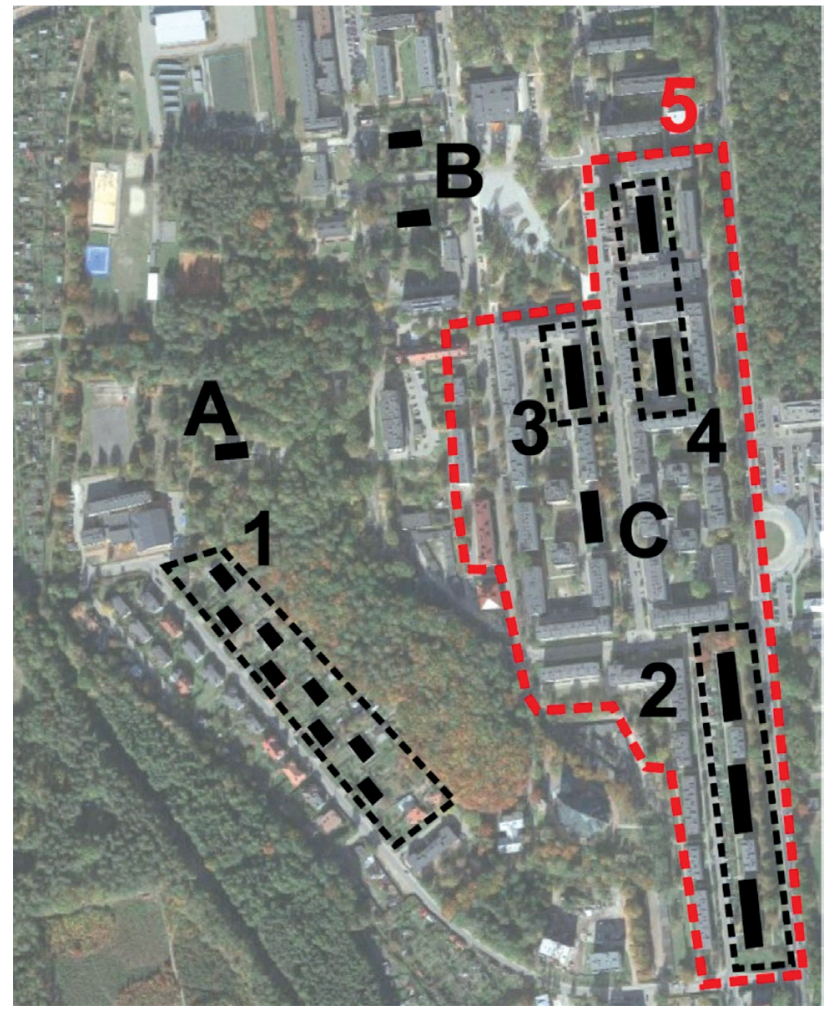

której wybudowane w latach 1937-1939 budynki, zarówno fabryczne jak i mieszkalne, zajęte były przez nazistów. Niestety, ze względu na krótki czas budowy, powstałe przed wojna wspólnoty były niezbyt stabilne i brakowato im poczucia zakorzenienia.

O procesie przekształcania się osiedli przyfabrycznych COP w miasta, które mieszkańcy mogliby nazywac domem można mówic dopiero W PRL-u. Odbudowa a wiaściwie dokonczenie zamystów urbanistycznych przedwojennych inżynierów w duchu socjalizmu pozwolita na uzupe hienie struktury osiedli a takze ppomieszanie grup społecznych, paradoksalnie pozwolito na wytworzenie się zazylości oraz wyksztalcenie więzi. Tkanka osiedlowa upodabniala się do miejskiej, szczególnie w okresie socrealizmu, kiedy to istniejąc budynki wąaczano w kwartały, lub quasi kwartały (Sta lowa Wola, Nowa Dęba), lub tworzono nowe pseud kwartały zabudowy zlokalizowane niezależnie od starych ukladów (Poniatowa, Nowa Sarzyna). Wytworzone $w$ ten sposób podworka, będąc przestreniami połpublicznymi, stawaly sie miejscem gdzie nawiazzywały sie in posid iny reprezentacyinych przestreni publicznych tożsaly reprezenta $z$ rynkmi hich przestreni publiczstowowolskie byty raczej przestrzeniami sasiedzkimi. W okresie powojennym powstawaty miejskie" domy kultury, czesto w stylu socrealistycznym (Stalowa Wola Nowa Sarzyna) lub inne ośrodki kultury: socrealistyczne np. kino Czyn w Poniatowej. W okresie miedzywo jennym na terenie osiedli funkcjonowały kilkuklasowe szkoły podstawowe (Stalowa Wola, Nowa Deba i Pionki). Natomiast bezpośrednio po wojnie oferta szkolnictwa zwiększyła sie i wybudowano budynki szkô
II. 1. Rudyment miasta Nowa Deba. Segregacja klasowa w ujeciu

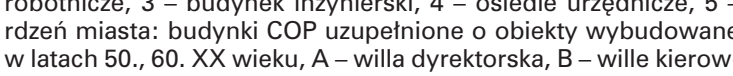
Wicze, C-hotel robotniczy (opracowanie wtasne)
III. 1. Rudiment of the town of Nowa Depa. Class segregation in
urban terms. Designations: 1 -foreman colony, 2 - workers' hous ing estate, 3 - enginieering building, $4-$ - officiail housing estate.
5 - town's core: CID buildings supplemented with facilities built the
the $1950 \mathrm{~s}, 1900 \mathrm{~s}$, A
ers' hotel lown study

communities formed before the war were not very stable and lacked a sense of rooting.

The process of transformation of CID factory estates into cities that residents could call home can only be talked about in the People's Republic of Poland. The reconstruction, or rather the completion of urban planning ideas of pre-war engineers in the spirt of socialism allowed to supplement the structure of he housing estates and also to mix up social groups, paradoxically it allowed for the creation of familiarity and the formation of bonds. The housing estate tissue was similar to the urban one, especially during the socialist realism period, when the existing (Stdings were included in quarters or quasi quarters Stalowa Wola, Nowa Dęba), or new pseudo building quarters were created located independently of the old systems (Poniatowa, Nowa Sarzyna). The courtyards created in this way, being semi-public spaces, became a place where fiendships and relationships did not have resestas, apant from Stalowa Wola with the mave of historical cities, and these from

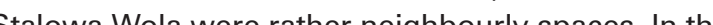
post-war period, "urban" cultural centres were cre ted, often in the socialist-realist style (Stalowa Wola Nowa Sarynal or other cultural centres: socialistrealist e g. the Czyn cinema in Poniatowa. In the interwar period, several-grade elementary schools (Stalowa Wola, Nowa Deba and Pionki) operated in the housing estate. However, immediately after the war, the educational offer increased and school build ings kept in the style of socialist realism were built: high school in Nowa Deba, primary schools in Nowa 


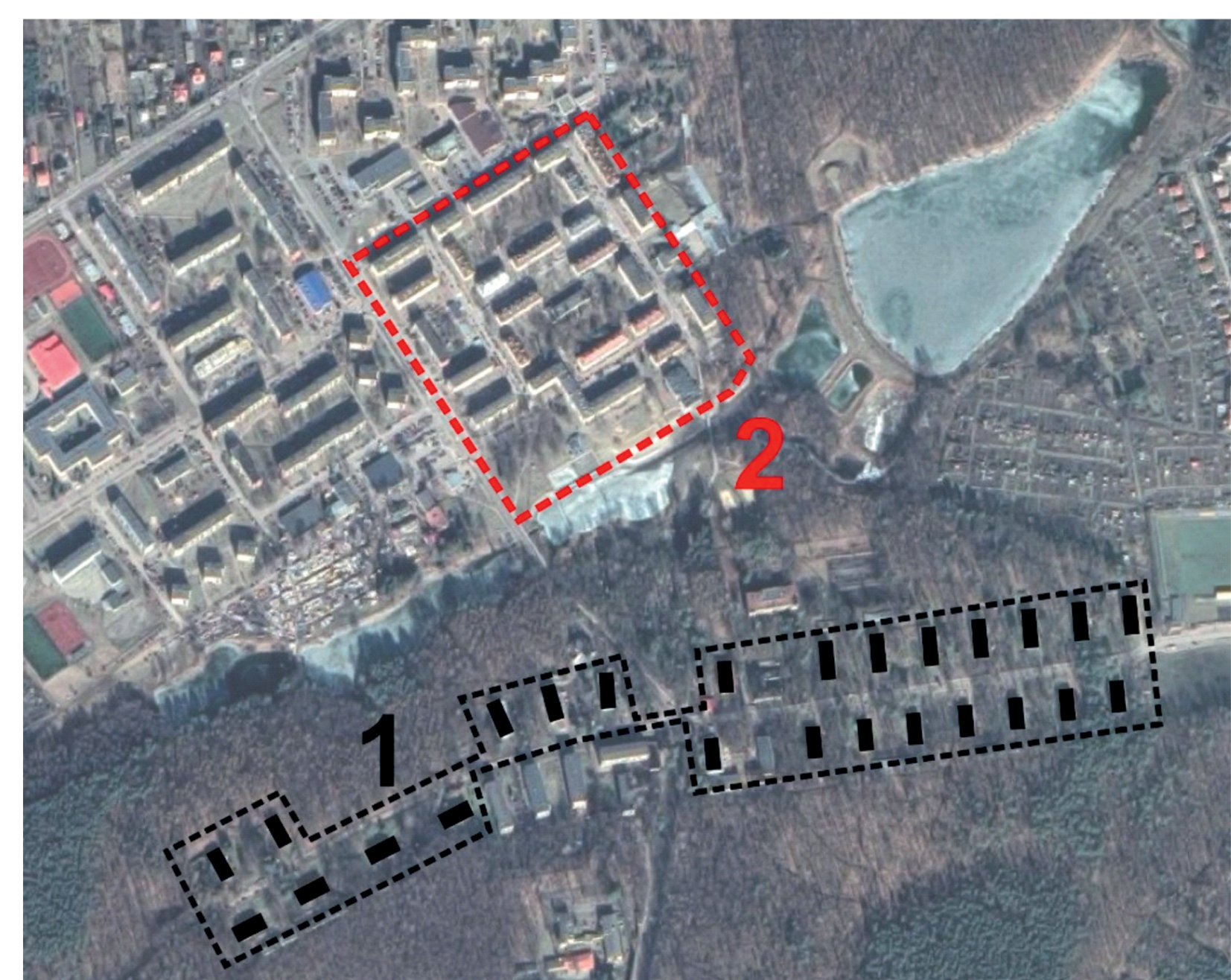

II. 2. Policentryczny układ zespołów miejskich Poniatowej. Oznaczenia: 1 - kolonia urzędnicza i inżynierska, 2 - nowe śródmieście wybudowane W latach 50., 60 . XX wieku (opracowanie whasne)
II. 2. Polycentric layout of urban complexes of Poniatowa. Designations: 1 - official and engineering colony, 2 - new downtown built in the 1950s,
1960s (own study)

utrzymane w stylu realizmu socjalistycznego: liceum w Nowej Dębie, szkoły podstawowe w Nowej Sarzynie i Poniatowej. Obiekty te budowane wewnątrz struktury miejskiej dawały szanse na integrację mieszkańców oraz przede wszystkim wpływały na jakość życia rodzin dając poczucie dobrego życia w komfortowym środowisku.

Z czasem osiedla przyfabryczne rozwinęły się na tyle ze otrzymaly prawa miejskie. W niektorych miastach ki (Nowa Deba, Nowa Sarzyna)6. Petnoprawne - rynrozwiiaty sie aź do czasćw transformacil ustrojowe w latach $90 \mathrm{XX}$ wieku, kiedy to zmienity sie zaw funkcjonowania zakładów na rynku. Prywatyzacja spo wodowała wyprzedawanie majatku i rozdrobnienie istniejacych zakładów. Zmieniła się dynamika rozwoju miast, wyraźnie przyśpieszyły miasta duże. Ponieważ ze względu na charakter produkcji małe miasta - osiedla funkcjonowały $w$ oddaleniu od większych ośrodków przemysłowych, młodzi ludzie emigrowali i pojawiaty się różne zjawiska kryzysowe, takie jak: bezrobocie, starość demograficzna, degradacja tkanki mieszkaniowe
Sarzyna and Poniatowa. These facilities built inside the city structure gave a chance for the integration of residents and, above all, influenced the quality of life of families, giving a sense of good life in a comfortble environment.

Over time, factory estates developed so much that they received city rights, In some cities, maor public spaces have evolved - markets (Nowa Deba, Nowa Sarzyna) ${ }^{6}$. Full-fledged cities developed until the time of political transformation in the 1990s, when the rules of the market's operations changed. Privatization hes caused the sale of assets and fragmentation of existing plants. The dynam ics of urban development changed, and large cities clearly accelerated. Because, due to the nature of production, small cities - settlements operated ta distance from larger industrial centres, young people emigrated and various crisis phenomena appeared, such as unemployment, demographic old age, degradation of the housing tissue and the public space ${ }^{7}$. Currently, the dynamics of life in the discussed settlement units is moderate and depends oraz przestrzeni publicznej'. Obecnie dynamika życia kowana i zależy od wielu czynnikow w tym przeksztarcen charakteru miejsc pracy. W większosci ośrodków funkcjonują oddziały stref ekonomicznych, szczegöln stref Europark WistoSan z siedzibą w Tarnobrzegu oraz Europark z siedzibą w Mielcu. Równocześnie okolic miast a takze same miasta coraz częsciej odwiedzan są przez turystow zainteresowanych zarowno turystyka przyrodnicza (Puszcza Sandomierska i liczne rezerwaty przyrody) jak i kulturową (modernistyczna architektura pozostałości po II Wojnie Światowej) $)^{8}$

\section{Podsumowanie}

Przedstawione w artykule przykłady przekształcen miast - osiedli", pokazuja zarys rozwoju lokowanych na surowym korzeniu jednostek w kontekście wpływu działań projektowych i morfologii budowanego obszaru na proces zakorzenienia, kreacji więzi oraz wspólnoty miejskiej a co za tym idzie poczucia życia w domu" w ujeciu psychologii i socjologii architektury oraz urbanistyki. Analiza literatury pokazuje, że pierwsze lat powstawania Centralnego Okregu Przemysłowego la zbyt krótkie i nerwowe aby wprowadzający sie mieszkańcy mogli nawiązać stosunki sassiedzkie. Nie sprzyja emu również segregacja klasowa - podział miast $n$ strefy przypisane do stanowisk jakie pełniono w głów nym zakładzie. Dopiero po II Wojnie Światowej, ideologia socjalistyczna nieco zrównała społeczeństwo, co $z$ czasem pozwoliło na wyksztalcenie małomiejskie wspólnoty.

PRZYPISY

Prawidtowość tą potwierdzaja przeprowadzone przez autorkę wywiad 2 mieszkańcami omawianych miast
Obszerną monografie, będaca, ko

M. Furtak, COP Centrallyy okreg prenemystowy 1936-1939. Architektura

- Wiecej na temat problemów spotecznych oraz zjawisk kryzysowych na dowy Centralnego Okregu Przemystowego [W:] Centralny Okreg Przem A. J. Kozzowski, A. Buszko, I. Z. Czaplicka-Kozłowska, s. 63-81 oraz W tucie is system administracyiny [w: Dzieie biurokracii tom VI, red. T. Byko-

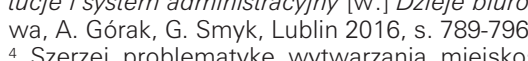

miejskiej w lokowanyych na suromym kerzonsisci i przeksztatceń tkan miejskiej W Wokowanych na surowym korzeniu miastach COP przedsta
wiono $\mathrm{W}$. S. Sikora, The development of small settlements in the industrial plant - city model - based on the examples of Nowa Deba and Nowa
Sarzyna, E3S Web Cont., Volume 45,2018 , VI International Conference of
Science and Technology Infraeko 2018 Modern Cities. Infrastructure and

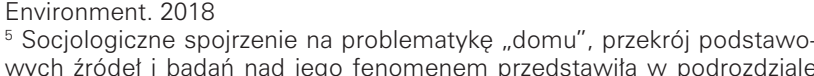
Dom i mata ojczyzna M. Cobel-Tokarska, Przestrzeń spoteczna: świat dom - miasto W. W. Krotkie wyktady z socjologii. Przeglad problemón i me
tod, red. A. Firkowska-Mankiewicz, T. Kanash, E. Tarkowska, Warszawa 2011 , s.57-59
6 O problemie powstawania przestrzeni publicznych $w$ matych miastac
picze A Siko w pisze A. Sikora W: Possibilities for Creating Public Spaces in a Small Town
Case Study, IOP Conf. Series: Materials Science and Engineering 603 ,

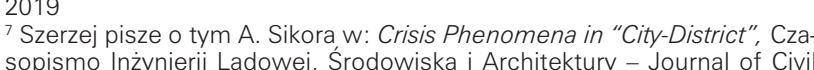
Engineering, Environment and Architecture. JCEEA, t. XXXV, V. 65 (4/18

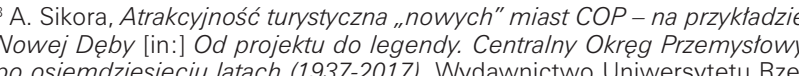
po osiemdziesieciu latach (1937-2017), Wydawnictwo Uniwersytetu Rze
szowskiego, Rzeszów 2018, s.341-352 on many factors, including the transformation of the (n) headquarters, especially Europark Wislosan The cinity of cities and the citit the same time, the a the cities themselves are more ature tourism (Sandomierz Forest and numerous nature reserves) and cultural tourism (modernist architecture of the Central Industrial District and remnants of World War III).

\section{Summary}

The examples of transformations of "cities - estates" presented in the article show the outline of the development of units located on the raw root in the contex of he impact or project activilies and morphology of the area being buil on the process of rooting, creat "if " for lite firstyear of esablisting vol vous for moving in residents to establish neighbouly elations. Class segrection also did not promote this the division of cities into zones assigned to posiions held in the main plant. It was only after World War II that socialist ideology slightly equalized World ty, which over time allowed the formation of a smal town community

ENDNOTES

This regularity is confirmed by the author's interviews with the
Thabitants of the cities in question 2 An extensive monograph, which is a compendium of knowledg ct 1936-1939. Architecture and Urban Planning, Publishing House Ksiezz Mityn, Krakow-Lodz 2014
$3 \mathrm{More}$ about social problems and crisis phenomena at the CID in
A. J. Koztowski, Socio-political condititions for the construction of the Central Industrial District lin:] Central Industrial District. Co A. J. Koztowski, A. Buszko, I. Z. Czaplicka-Koztowska, p. 63-8 and W. Chuddik, Central Industrial Iistrict (1937-1939)- people
offices, institutions and administrative system lin:l History of bureaucracy volume VI, ed. T. Bykowa, A. Górak, G. Smyk, Lublin
2016 . 7899796 2016, p. $789-796$
4The issue of urban creation and transformation of the urban tissue small settlements in the industrial plant - city model - based on the
examples of Nowa Depa and Nowa Sarzyna, E3S Web Conf., Voluexamples of Nowa Deba and Nowa Sarzyna, E3S Web Conf., Volu-
me 45,2018, VI International Conference of Science and Techno-
logy Infraeko 2018 Modern Cities. Infrastructure and Environment. A sociological view of the issue of a "house", a cross-section of
"asic sources and research on its phenomenen is presented in the subsection Home and a small homeland M. Cobel-Tokarska, Socia of problems and methods, ed. A. Firkowska-Mankiewicz, T. Kanash. E. Tarkowska, Warszawa 2011, p. $57-59$
The problem of the creation of public spaces in small cities is The problem of the creation of public spaces in small cities is
described by A. Sikora in: Possibilities for Creating Public Spaces in
Small Town: Case Study. IOP Conf. Series: Materials Science an a Small Town: Case Stud $P$,
Engineering 603,2019

Engineering 603, 2019
"This is described in more details by A. Sikora in: Crisis Pheno-
mena in "City-Estate"", Czasopismo Inżynierii Ladowej, Srodowiska Architektury - Journal of Civil Engineering, Environment and Arc A. Sikore To, . XXXV, V. 65 (4/18), Rzesz EN

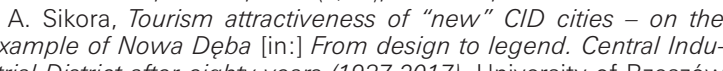
strial District after eighty years (1937-2017),
Publishing House, Rzeszów 2018, p. 341-352 


\section{LITERATURA}

[1] W. Chudzik, Centralny Okręg Przemysłowy (1937-1939) - Iudzie, urzedy, instytucje i system administracyjny [w:] Dzieje biurokracji tom VI, red. T. Bykowa, A. Górak, G. Smyk, Lublin 2016, s. 789-796

[2] M. Cobel-Tokarska, Przestrzeń społeczna: świat - dom - miasto [w:] Krótkie wykłady z socjologii. Przegląd problemów i metod, red. A. Firkowska-Mankiewicz, T. Kanash, E. Tarkowska, Warszawa 2011, s. $45-61$

[3] M. Furtak, COP Centralny okreg przemystowy 1936-1939. Architektura i Urbanistyka, Dom Wydawniczy Księży Młyn, Kraków-Łódź 2014

[4] A. J. Kozłowski, Społeczno-polityczne uwarunkowania budowy Centralnego Okregu Przemysłowego [w:] Centralny Okreg Przemystowy. Koncepcja i realizacja w artykułach prasowych z lat 1935-1939, red. A. J. Kozłowski, A. Buszko, I. Z. Czaplicka-Kozłowska, s. 63-81

[5] A. Sikora, Atrakcyjność turystyczna "nowych" miast COP - na przykładzie Nowej Dęby [in:] Od projektu do legendy. Centralny Okręg Przemystowy po osiemdziesięciu latach (1937-2017), Wydawnictwo Uniwersytetu Rzeszowskiego, Rzeszów 2018, s. 341-352

[6] A. Sikora, Crisis Phenomena in "City-District", Czasopismo Inżynierii Lądowej, Środowiska i Architektury - Journal of Civil Engineering, Environment and Architecture. JCEEA, t. XXXV, V. 65 (4/18), Rzeszów, 2018 [7] A. Sikora, The development of small settlements in the industrial plant - city model - based on the examples of Nowa Deba and Nowa Sarzyna, E3S Web Conf., Volume 45, 2018, VI International Conference of Science and Technology Infraeko 2018 Modern Cities. Infrastructure and Environment. 2018

[8] A. Sikora, Possibilities for Creating Public Spaces in a Small Town: Case Study, IOP Conf. Series: Materials Science and Engineering 603, 2019

\section{BIBLIOGRAPHY}

[1] W. Chudzik, Central Industrial District (1937-1939) - people, offices, institutions and administrative system [in:] History of bureaucracy volume VI, ed. T. Bykowa, A. Górak, G. Smyk, Lublin 2016, p. 789-796

[2] M. Cobel-Tokarska, Social space: world - home - city [in:] Short lectures on sociology. Review of problems and methods, ed. A. Firkowska-Mankiewicz, T. Kanash, E. Tarkowska, Warszawa 2011, p. 45-61

[3] M. Furtak, CID Central Industrial District 1936-1939. Architecture and Urban Planning, Publishing House Księży Młyn, Kraków-Łódź 2014

[4] A. J. Kozłowski, Socio-political conditions of the construction of the Central Industrial District [in:] Central Industrial District. Concept and implementation in press articles from 1935-1939, ed. A. J. Kozłowski, A. Buszko, I. Z. Czaplicka-Kozłowska, p. 63-81

[5] A. Sikora, Tourist attractiveness of "new" CID cities - on the example of Nowa Dęba [in:] From design to legend. Central Industrial District after eighty years (1937-2017), University of Rzeszów Publishing House, Rzeszów 2018, p. 341-352

[6] A. Sikora, Crisis Phenomena in "City-Estate", Czasopismo Inżynierii Lądowej, Środowiska i Architektury - Journal of Civil Engineering, Environment and Architecture. JCEEA, t. XXXV, V. 65 (4/18), Rzeszów, 2018

[7] A. Sikora, The development of small settlements in the industrial plant - city model - based on the examples of Nowa Dęba and Nowa Sarzyna, E3S Web Conf., Volume 45, 2018, VI International Conference of Science and Technology Infraeko 2018 Modern Cities. Infrastructure and Environment. 2018

[8] A. Sikora, Possibilities for Creating Public Spaces in a Small Town: Case Study, IOP Conf. Series: Materials Science and Engineering 603, 2019 